\title{
Biochemical and hematological parameters in European sea bass (Dicentrarchus labrax Linnaeus, 1758) and Gilthead sea bream (Sparus aurata Linnaeus, 1758) in relation to temperature
}

\author{
Francesco Fazio ${ }^{1 *}$, Vincenzo Ferrantelli², Giuseppe Piccione ${ }^{1}$, \\ Concetta Saoca ${ }^{1}$, Maria Levanti ${ }^{1}$, and Massimo Mucciardi ${ }^{3}$ \\ ${ }^{I}$ Department of Veterinary Sciences, Polo Universitario Annunziata, University of Messina, Messina, Italy \\ ${ }^{2}$ Experimental Zooprophylaxy Institute of Sicily “A. Mirri”, Palermo, Italy \\ ${ }^{3}$ Department of Economics, University of Messina, University of Messina, Messina, Italy
}

FAZIO, F., V. FERRANTELLI, G. PICCIONE, C. SAOCA, M. LEVANTI, M. MUCCIARDI: Biochemical and hematological parameters in European sea bass (Dicentrarchus labrax Linnaeus, 1758) and Gilthead sea bream (Sparus aurata Linnaeus, 1758) in relation to temperature. Vet. arhiv 88, 397-411, 2018.

\section{ABSTRACT}

In order to evaluate the influence of temperature on biochemical and hematological parameters in two different farmed fish, the gilthead sea bream (Sparus aurata Linnaeus, 1758) and the European sea bass (Dicentrarchus labrax, Linnaeus, 1758), blood samples were collected from a total of 60 specimens of each species, reared in Sicily, in the cold (February, mean temperature $13.40{ }^{\circ} \mathrm{C}$ ) and warm seasons (October, mean temperature $23.20^{\circ} \mathrm{C}$ ). Biochemical (glucose, lactate, cholesterol, triglycerides and total protein) and hematological (red blood cell RBC, hemoglobin concentration Hgb, hematoctit Hct, mean corpuscular volume $\mathrm{MCV}$, mean corpuscular hemoglobin $\mathrm{MCH}$ and mean corpuscular hemoglobin concentration $\mathrm{MCHC}$ ) parameters were evaluated. Significant differences $(\mathrm{P}<0.05)$ were observed for glucose, lactate, triglycerides, cholesterol, total protein and $\mathrm{RBC}, \mathrm{Hgb}, \mathrm{Hct}, \mathrm{MCV}$, and $\mathrm{MCH}$. This information could be useful for optimization of the husbandry practices in land-based aquaculture, and provide useful information for monitoring changes in the health status of fish.

Key words: blood parameters; farmed fish; growth; season; water temperature

\section{Introduction}

In European marine aquaculture, European sea bass (Dicentrarchus labrax Linnaeus, 1758) represents a very important species. The natural populations have been widely

\footnotetext{
${ }^{*}$ Corresponding author:

Prof. Francesco Fazio, Department of Veterinary Sciences, Polo Universitario Annunziata, University of Messina, 98168 Messina, Italy, Phone: +39 090350 3516; Fax: +39 090350 3975; E-mail: ffazio@unime.it
} 
exploited, therefore appropriate management and conservation measures are necessary. In both farming conditions and the natural environment, the reproduction of sea bass takes place in temperatures between 11 and $15{ }^{\circ} \mathrm{C}$. The gilthead sea bream Sparus aurata (Linnaeus, 1758) is largely farmed around the Mediterranean area, and the main centers of its production are Turkey, Greece, Italy and Spain (PARISI et al., 2014).

Environmental stress alters homeostasis and influences biological functions (GRACEY et al., 2004). Physical and chemical processes within biological systems are strongly influenced by temperature (SCOTT and JOHNSTON 2012). Temperature is one of the common variables in the aquatic environment that directly affect the survival of marine organisms. Under culture conditions, fluctuations in water temperature governed by seasonal shifts affect the immune system and other physiological functions, such as growth efficiency through enzyme activity, and reproduction. However, sudden fluctuations in water temperature that exceed the threshold values often cause the death of fish (CHATTERJEE et al., 2004; CHENG et al., 2013). Some authors have indicated that species with similar thermal preferences may respond differently to the same subdaily temperature fluctuations (COULTER et al., 2016). Fish farmers aim to improve fish welfare, to guarantee successful farming, and to mitigate disease outbreaks in aquaculture that cause substantial economic loss. Therefore it is necessary to develop control strategies based on a better understanding of the effects of environmental stressors on the health status of farmed fish (BOWDEN et al., 2007). The study of the hematological and biochemical parameters in cultured fish species is an important tool in the development of aquaculture systems (O'NEAL and WEIRICH, 2001; PERCIN and KONYALIOGLU, 2008; MAURI et al., 2011). These parameters provide information not only about the health status of fish and the water quality in which they live, but also help to foresee, at some level, the susceptibility of organisms to changes in environmental conditions (PERCIN et al., 2010; AYOOLA et al., 2011). The physiological and metabolic response of fish to environmental changes can be examined using hematological and biochemical parameters, because blood constituents respond rapidly to any factor that affects homeostasis, including the influences of the habitat (LOHNER et al., 2001, CAZENAVE et al., 2005; ELAHEE and BHAGWANT, 2007). Rapid temperature changes have the potential to dramatically affect physiological processes in aquatic organisms and, due to their limited mobility, fish in their early life stages are particularly vulnerable to ambient temperature fluctuations (COULTER et al., 2015). Previous research showed monthly variations of biochemical and hematological parameters in sea bream and sea bass reared in Mediterranean off-shore tanks (FAGGIO et al., 2014a, 2014 b). The aim of this study was to investigate biochemical (glucose, lactate, cholesterol, triglycerides and total protein) and hematological (red blood cell RBC, hemoglobin concentration Hgb, hematocrit Hct, mean corpuscular volume MCV, mean corpuscular hemoglobin $\mathrm{MCH}$ and mean corpuscular hemoglobin concentration $\mathrm{MCHC}$ ) parameters, and growth indices 
(weight, length, viscero-somatic index VSI and condition factor CF) in $S$. aurata and $D$. labrax during two different seasons (the warm period in October, $23.20{ }^{\circ} \mathrm{C}$ and the cold period in February, $13.40^{\circ} \mathrm{C}$ ) in order to evaluate the effect of temperature.

\section{Materials and methods}

The study was conducted by collecting a total of 120 fish: 60 Sparus aurata (144.62 $\pm 13.49 \mathrm{~g}$ weight; $19.58 \pm 0.93 \mathrm{~cm}$ length) and 60 Dicentrarchus labrax (142.24 \pm 11.82 g weight; $19.09 \pm 0.55 \mathrm{~cm}$ length) from a Sicilian fish farm. Fish, reared in land-based outside tanks $\left(210 \mathrm{~m}^{3}\right)$ in an open aquaculture system with a continuous supply of sea water, were subjected to natural environmental conditions (photoperiod and water temperature); stocking density was $31 \mathrm{~kg} \cdot \mathrm{m}^{-3}$ for sea bass and $36 \mathrm{~kg} \cdot \mathrm{m}^{-3}$ for sea bream.

The fish were fed twice $(9.00 ; 18: 00)$ every day, equally in the two periods, with a commercial diet specific for the two species, containing different levels of protein and lipid (47/20\% for sea bream and 45/20\% for sea bass respectively) (Skretting Italia. SpA, Mozzecane, Verona, Italia).

Table 1. Environmental parameters recorded in the aquaculture implant during the two sampling season

\begin{tabular}{|l|c|c|c|}
\hline Month & Photoperiod (L/D) & Temperature $\left({ }^{\circ} \mathrm{C}\right)$ & Dissolved oxygen $(\mathrm{mg} / \mathrm{dL})$ \\
\hline October & $13 / 11$ & $23.20 \pm 0.22$ & $3.8 \pm 0.05$ \\
\hline February & $12 / 12$ & $13.40 \pm 0.18$ & $5.6 \pm 0.07$ \\
\hline
\end{tabular}

On the basis of the environmental recordings from the previous year, it was decided to sample the fish at the periods' extreme water parameters; the warmest time, in October (mean temperature $23.20 \pm 0.22^{\circ} \mathrm{C}$ ) and the coldest time, in February (mean temperature $13.40 \pm 0.18^{\circ} \mathrm{C}$ ). On the farm, water temperature and dissolved oxygen were tested five times at 8.00 a.m. in October and five times in February, at a depth of two meters. Table 1 shows the environmental parameters recorded in the aquaculture implant during the two sampling season. All fish were considered clinically healthy on the basis of an external examination for any signs of abnormalities or infestation, came from the two different production batches on the same farm and were kept in two different tanks with similar biometric indices (Table 2). Fish were randomly sampled before feeding from the same batch, by confinement and netting in the tanks. The fish were anaesthetized prior to blood sampling using 2-Phenoxyethanol (99\%, MERCK, Whitehouse Station, NJ, USA) at a concentration of $400 \mathrm{ppm}$. Immediately after the anaesthetization procedure, the fish were individually weighed to the nearest 0.01g (Mark 2200, BEL Engineering Srl, Monza), their fork length $(L)$ was recorded and finally they underwent venipuncture. At the end of the blood sampling, visceral weight $(W v)$, including liver, spleen, pancreas and intestines) was recorded. Growth performance was assessed using condition factor (CF), and the viscero-somatic index (VSI), as reported in Table 2. 
For each season, $\mathrm{CF}$ was calculated as:

$W \times 100 L^{-3}$, where $W$ is the weight of animal and $L$ is the length;

VSI was calculated as:

$W v \times 100 / \mathrm{W}$, where $\mathrm{Wv}$ is the visceral weight and $W$ wet weight.

Table 2. Parameters useful to assess growth performance of $S$. aurata $(\mathrm{n}=30$ each month) and D. labrax $(\mathrm{n}=30$ each month): condition factor $(\mathrm{CF})$ and viscero-somatic index (VSI). Sample obtained on two different production batches

\begin{tabular}{|l|c|c|c|c|c|c|}
\hline \multirow{2}{*}{ Months } & & $\begin{array}{c}\text { Weight } \\
(\mathrm{g})\end{array}$ & $\begin{array}{c}\text { Visceral weight } \\
(\mathrm{g})\end{array}$ & $\begin{array}{c}\text { Fork length } \\
(\mathrm{cm})\end{array}$ & VSI & CF \\
\hline \multirow{2}{*}{$\begin{array}{l}\text { October } \\
2013\end{array}$} & S. aurata & $145.40 \pm 12.96$ & $11.62 \pm 1.77$ & $19.78 \pm 0.91$ & 7.99 & 1.91 \\
\cline { 2 - 7 } & D. labrax & $142.52 \pm 11.05$ & $13.34 \pm 1.77$ & $19.38 \pm 0.99$ & 7.96 & 1.98 \\
\hline $\begin{array}{l}\text { February } \\
2014\end{array}$ & S. aurata & $143.84 \pm 14.02$ & $11.26 \pm 2.10$ & $19.38 \pm 0.96$ & 7.81 & 2.01 \\
\cline { 2 - 7 } & D. labrax & $141.97 \pm 12.59$ & $10.90 \pm 2.00$ & $18.80 \pm 1.12$ & 7.68 & 2.18 \\
\hline
\end{tabular}

Blood samples were obtained from the caudal vein using a $20 \mathrm{G} \times 1 \frac{1}{2}$ syringe, and were collected in two tube types: microtubes (Miniplast $0.6 \mathrm{~mL}$, LP Italiana Spa, Milano) containing EDTA (ratio $1.26 \mathrm{mg} / 0.6 \mathrm{~mL}$ ) as the anticoagulant agent to assess Red Blood (RBC), Hematocrit (Hct), Hemoglobin concentration (Hgb), Mean Corpuscular Volume (MCV), Mean Corpuscular Haemoglobin (MCH) and Mean Corpuscular Haemoglobin Concentration (MCHC); and non-heparinised tubes to test serum total protein, cholesterol and triglycerides. For assessment of glucose and lactate in the whole blood, portable blood glucose (ACCU-Chek Active, Roche Diagnostics GmbH, Mannheim, Germany) and portable blood lactate analyzers (Accusport, Boehringer Mannheim, Germany) were used.

The time elapsing from capture to blood collecting was less than $5 \mathrm{~min}$. To assess RBC, Hgb, Hct, MCV, MCH, MCHC values, a blood cell counter HeCo Vet C (SEAC, Florence, Italy) was used. As previously described in S. aurata (FAZIO et al. 2012; 2013). Falcon tubes were centrifuged at room temperature at $1300 \mathrm{~g}$ for $10 \mathrm{~min}$ and the obtained serum was stored at $-20^{\circ} \mathrm{C}$ and analyzed 20 days later. The concentrations of serum total proteins (TP), cholesterol and triglycerides were determined by means of commercial kits (SEAC, Florence, Italy) using an automated UV Spectrophotometer (SEAC, Slim, Florence, Italy).

All samples were analyzed in triplicate by the same operator. The samples exhibited parallel displacement to the standard curve. The overall intra-assay coefficient of variation was $<5 \%$. The protocols of animal husbandry and experimentation were reviewed and approved in accordance with the standards recommended by the Guide for the Care and Use of Laboratory Animals, and Directive 2010/63/EU for animal experiments.

Approval for the project PON INNOVAQUA(PON02_00451_3362185) was granted by the Italian Ministry of Universities and Research (MIUR). 
Statistical analysis. Blood parameters and the biometric index were compared between seasons (warm temperature $v s$. cold temperature) in both species using the t-test; when the assumption of homogeneity of variance was not met, the Welch test was used. Results were considered significant at a P-value less than 0.05 and were verified with the Monte Carlo method (with 10.000 samples). Furthermore, Pearson's correlation analysis was utilized for each species of fish separately to calculate the correlations of the blood parameters in the two different water temperatures (Tables 3 and 4).

Table 3. Correlation matrix among the hematological and biochemical parameters of Sparus aurata (Linnaeus, 1758) in warm and cold water

\begin{tabular}{|l|l|l|l|l|l|l|l|l|l|l|l|l|}
\hline & Water & RBC & Hgb & Hct & MCV & MCH & MCHC & GLU & LAC & TRIG & CHOL & TP \\
\hline RBC & warm & - & & & & & & & & & & \\
\hline & cold & - & & & & & & & & & & \\
\hline Hgb & warm & & - & & & & & & & & & \\
\hline & cold & $0.556^{* *}$ & - & & & & & & & & & \\
\hline Hct & warm & & & - & & & & & & & & \\
\hline & cold & $0.462^{*}$ & & - & & & & & & & & \\
\hline MCV & warm & $-0.896^{* *}$ & $0.462^{*}$ & & - & & & & & & & \\
\hline & cold & $-0.788^{* *}$ & & & - & & & & & & & \\
\hline MCH & warm & $-0.717 * *$ & & $0.483 * *$ & $0.639^{* *}$ & - & & & & & & \\
\hline & cold & $-0.602^{* *}$ & & $0.423^{*}$ & $0.477 * *$ & - & & & & & & \\
\hline MCHC & warm & & $0.535^{* *}-0.873^{* *}$ & $0.421^{*}$ & $-0.422^{*}$ & - & & & & & \\
\hline & cold & & $0.390^{*}$ & $-0.745^{* *}$ & $0.406^{*}$ & $-0.604 * *$ & - & & & & & \\
\hline GLU & warm & & & $0.405^{*}$ & & & $0.438^{*}$ & - & & & & \\
\hline & cold & & & & & & & - & & & & \\
\hline LAC & warm & & & & & & & & - & & & \\
\hline & cold & & & & & & & & - & & & \\
\hline TRIG & warm & $-0.400^{*}$ & & & & & & & & - & & \\
\hline & cold & & & & & & & & & - & & \\
\hline CHOL & warm & & & & & & & & & & - & \\
\hline & cold & $0.535^{*}$ & & & $-0.562 * *$ & $-0.533^{* *}$ & & $0.417 *$ & & - & \\
\hline TP & warm & & & & & & & & & & & - \\
\hline & cold & & & & & & & $-0.370 *$ & & & - \\
\hline
\end{tabular}

*Correlation is significant for $\mathrm{P}<0.05$; **Correlation is significant for $\mathrm{P}<0.01$; Red blood cell (RBC); Haemoglobin concentration (Hgb); Haematocrit (Hct); Mean corpuscular volume (MCV); Mean corpuscular haemoglobin (MCH); Mean corpuscular haemoglobin concentration (MCHC); Glucose (GLU); Lactate (LAC); Triglycerides (TRIG); Cholesterol (CHOL); Serum total proteins (TP) 
F. Fazio et al.: The effect of temperature and blood parameters in fish

Table 4. Correlation matrix among the hematological and biochemical parameters of Dicentrarchus labrax (Linnaeus, 1758) in warm and cold water

\begin{tabular}{|l|l|l|l|l|l|l|l|l|l|l|l|l|}
\hline & Water & RBC & Hgb & Hct & MCV & MCH & MCHC & GLU & LAC & TRIG & CHOL & TP \\
\hline RBC & warm & - & & & & & & & & & & \\
\hline & cold & - & & & & & & & & & & \\
\hline Hgb & warm & & - & & & & & & & & & \\
\hline & cold & $0.556^{* *}$ & - & & & & & & & & & \\
\hline Hct & warm & & & - & & & & & & & & \\
\hline & cold & $0.462^{*}$ & & - & & & & & & & & \\
\hline MCV & warm & $-0.896^{* *}$ & $0.462^{*}$ & & - & & & & & & & \\
\hline & cold & $-0.788^{* *}$ & & & - & & & & & & & \\
\hline MCH & warm & $-0.717^{* *}$ & & $0.483^{* *}$ & $0.639^{* *}$ & - & & & & & & \\
\hline & cold & $-0.602^{* *}$ & & $0.423^{*}$ & $0.477^{* *}$ & - & & & & & & \\
\hline MCHC & warm & & $0.535^{* *}$ & $-0.873^{* *}$ & $0.421^{*}$ & $-0.422^{*}$ & - & & & & & \\
\hline & cold & & $0.390^{*}$ & $-0.745^{* *}$ & $0.406^{*}$ & $-0.604^{* *}$ & - & & & & & \\
\hline GLU & warm & & & $0.405^{*}$ & & & $0.438^{*}$ & - & & & & \\
\hline & cold & & & & & & & - & & & & \\
\hline LAC & warm & & & & & & & & - & & & \\
\hline & cold & & & & & & & & - & & & \\
\hline TRIG & warm & $-0.400^{*}$ & & & & & & & & - & & \\
\hline & cold & & & & & & & & & - & & \\
\hline CHOL & warm & & & & & & & & & & - & \\
\hline & cold & $0.535^{*}$ & & & $-0.562^{* *}$ & $-0.533^{* *}$ & & $0.417 *$ & & - & \\
\hline TP & warm & & & & & & & & & & & - \\
\hline & cold & & & & & & & $-0.370 *$ & & & - \\
\hline
\end{tabular}

*Correlation is significant for $\mathrm{P}<0.05$; **Correlation is significant for $\mathrm{P}<0.01$; Red blood cell (RBC); Haemoglobin concentration (Hgb); Haematocrit (Hct), Mean corpuscular volume (MCV); Mean corpuscular haemoglobin (MCH); Mean corpuscular haemoglobin concentration (MCHC); Glucose (GLU); Lactate (LAC); Triglycerides (TRIG); Cholesterol (CHOL); Serum total proteins (TP).

All calculations were performed using the R statistical language package, ver. 2.13.

\section{Results}

The unpaired $t$-test did not show any significant differences in biometric indices during the sampling periods (Table 2). In both species the unpaired t-test showed significant changes in all parameters except MCHC. Lactate, triglycerides, Hgb, Hct, MCV and MCH values showed the same trends in both species, while glucose, cholesterol, total protein, $\mathrm{RBC}$ and $\mathrm{MCHC}$ values displayed different trends between the two species. Mean values and standard deviations, with statistical differences between the times of sampling (warm 
$v s$. cold) and the percentage of variation recorded in all parameters evaluated in S. aurata and D. labrax, are reported in Table 5.

Table 5. Mean values and standard deviations together the statistical differences between the times of sampling (warm $v s$ cold) and percent changes variation recorded in all parameters studied in Sparus aurata (Linnaeus, 1758) and Dicentrarchus labrax (Linnaeus, 1758)

\begin{tabular}{|c|c|c|c|c|c|c|}
\hline \multirow[b]{2}{*}{ Parameters } & \multicolumn{3}{|c|}{ S. aurata } & \multicolumn{3}{|c|}{ D. labrax } \\
\hline & Warm & Cold & \begin{tabular}{|l|}
$\begin{array}{l}\text { Percent } \\
\text { change }\end{array}$ \\
\end{tabular} & Warm & Cold & $\begin{array}{l}\text { Percent } \\
\text { change }\end{array}$ \\
\hline $\begin{array}{l}\text { Glucose } \\
(\mathrm{mg} / \mathrm{dL})\end{array}$ & $\begin{array}{c}109.30 \\
\pm 12.16^{*}\end{array}$ & $\begin{array}{l}244.50 \\
\pm 12.96\end{array}$ & $124 \%$ & $\begin{array}{c}217.60 \\
\pm 25.74 *\end{array}$ & $\begin{array}{l}181.90 \\
\pm 30.85\end{array}$ & $-16.40 \%$ \\
\hline $\begin{array}{l}\text { Lactate } \\
(\mathrm{mmol} / \mathrm{L})\end{array}$ & $\begin{array}{l}9.27 \\
\pm 0.92 *\end{array}$ & $\begin{array}{c}3.46 \\
\pm 0.57\end{array}$ & $-62.64 \%$ & $\begin{array}{c}17.98 \\
\pm 2.29 *\end{array}$ & $\begin{array}{l}11.02 \\
\pm 1.44\end{array}$ & $-38.71 \%$ \\
\hline $\begin{array}{l}\text { Triglycerides } \\
\text { (g/dL) }\end{array}$ & $\begin{array}{l}211.00 \\
\pm 35.28^{*}\end{array}$ & $\begin{array}{l}333.70 \\
\pm 32.52\end{array}$ & $58.15 \%$ & $\begin{array}{c}318.40 \\
\pm 21.56^{*}\end{array}$ & $\begin{array}{l}565.70 \\
\pm 75.13 \\
\end{array}$ & $77.67 \%$ \\
\hline $\begin{array}{l}\text { Cholesterol } \\
(\mathrm{g} / \mathrm{dL})\end{array}$ & $\begin{array}{l}231.50 \\
\pm 24.14^{*}\end{array}$ & $\begin{array}{l}251.00 \\
\pm 15.57\end{array}$ & $8.42 \%$ & $\begin{array}{l}222.20 \\
\pm 26.66\end{array}$ & $\begin{array}{l}209.70 \\
\pm 22.51\end{array}$ & $-5.63 \%$ \\
\hline $\begin{array}{l}\text { Total Protein } \\
(\mathrm{g} / \mathrm{dL})\end{array}$ & $\begin{array}{c}4.33 \\
\pm 0.49 *\end{array}$ & $\begin{array}{c}3.42 \\
\pm 0.38\end{array}$ & $-21.1 \%$ & $\begin{array}{c}3.73 \\
\pm 0.29 *\end{array}$ & $\begin{array}{c}4.08 \\
\pm 0.79\end{array}$ & $9.38 \%$ \\
\hline $\begin{array}{l}\mathrm{RBC} \\
\left(\times 10^{12} / \mathrm{L}\right)\end{array}$ & $\begin{array}{c}3.48 \\
\pm 0.51^{*}\end{array}$ & $\begin{array}{l}2.90 \\
\pm 0.31\end{array}$ & $-16.65 \%$ & $\begin{array}{c}3.02 \\
\pm 0.66^{*}\end{array}$ & $\begin{array}{c}4.01 \\
\pm 0.60\end{array}$ & $32.92 \%$ \\
\hline $\begin{array}{l}\mathrm{Hgb} \\
(\mathrm{g} / \mathrm{dL})\end{array}$ & $\begin{array}{c}9.62 \\
\pm 0.74 * \\
\end{array}$ & $\begin{array}{l}10.26 \\
\pm 0.67\end{array}$ & $6.68 \%$ & $\begin{array}{l}6.67 \\
\pm 0.87 * \\
\end{array}$ & $\begin{array}{l}10.60 \\
\pm 1.10\end{array}$ & $58.92 \%$ \\
\hline $\begin{array}{l}\text { Het } \\
(\%)\end{array}$ & $\begin{array}{l}42.58 \\
\pm 5.12 * \\
\end{array}$ & $\begin{array}{l}46.62 \\
\pm 4.27 \\
\end{array}$ & $9.48 \%$ & $\begin{array}{c}32.00 \\
\pm 3.48^{*} \\
\end{array}$ & $\begin{array}{l}48.38 \\
\pm 4.81 \\
\end{array}$ & $51.18 \%$ \\
\hline $\begin{array}{l}\mathrm{MCV} \\
\text { (fL) }\end{array}$ & $\begin{array}{l}124.50 \\
\pm 20.22^{*}\end{array}$ & $\begin{array}{l}161.90 \\
\pm 16.14 \\
\end{array}$ & $30.04 \%$ & $\begin{array}{c}109.40 \\
\pm 18.83 * \\
\end{array}$ & $\begin{array}{l}122.20 \\
\pm 14.66 \\
\end{array}$ & $11.70 \%$ \\
\hline $\begin{array}{l}\mathrm{MCH} \\
(\mathrm{pg})\end{array}$ & $\begin{array}{c}28.26 \\
\pm 4.77^{*} \\
\end{array}$ & $\begin{array}{l}35.65 \\
\pm 3.03 \\
\end{array}$ & $26.15 \%$ & $\begin{array}{c}23.28 \\
\pm 6.60^{*} \\
\end{array}$ & $\begin{array}{l}26.82 \\
\pm 3.62 \\
\end{array}$ & $-15.20 \%$ \\
\hline $\begin{array}{l}\mathrm{MCHC} \\
(\mathrm{g} / \mathrm{dL})\end{array}$ & $\begin{array}{l}22.91 \\
\pm 3.22 \\
\end{array}$ & $\begin{array}{l}22.14 \\
\pm 2.02 \\
\end{array}$ & $-3.36 \%$ & $\begin{array}{l}21.07 \\
\pm 3.41 \\
\end{array}$ & $\begin{array}{l}21.96 \\
\pm 1.53 \\
\end{array}$ & $4.20 \%$ \\
\hline
\end{tabular}

*Warm vs Cold $(\mathrm{P}<0.05)$; Red blood cell $(\mathrm{RBC})$; Haemoglobin concentration (Hgb); Haematocrit (Hct); Mean corpuscular volume (MCV); Mean corpuscular haemoglobin (MCH); Mean corpuscular haemoglobin concentration (MCHC).

Some of the biochemical and hematological parameters obtained from $S$. aurata $(\mathrm{n}=$ $60)$ and $D$. labrax respectively $(n=60)$ were significantly correlated in the two different experimental periods (warm and cold water temperature) (Tables 3 and 4). 


\section{F. Fazio et al.: The effect of temperature and blood parameters in fish}

\section{Discussion}

Our data showed a variation of biochemical and hematological parameters in relation to two different water temperatures. Temperature is one of the common variables in the aquatic environment that influence oxygen solubility in water $(\mathrm{CECH}$ and BRAUNER, 2011), and hence fish must respond by changing their blood parameters.

Under culture conditions, fluctuations in water temperature affect the blood, and sudden fluctuations in water temperature that exceed the threshold values often cause the death of fish (CHATTERJEE et al., 2004; CHENG et al., 2013). Hematological parameters are likely to change according to the changes in the aquatic environment; they can help us to understand the process of adaptation of animals to their environment (RANZANI-PAIVA et al., 2005), and provide references to identify any changes in the condition of the fish's health.

Changes in the hematological and biochemical responses to water temperature have been studied in rainbow trout (Oncorhynchus mykiss), goldfish (Carassius auratus), Atlantic cod (Gadus morhua), tilapia (Oreochromis mossambicus), olive flounder (Paralichthys olivaceus) and silver catfish (Schilbe Intermedius) (BASU et al., 2001; LERMEN et al., 2004; YANG and YEO, 2004; GOLLOCK et al., 2006; HUR and HABIBI, 2007; JEONG et al., 2012).

S. aurata from this study showed higher RBC during the warm period, probably due to the fact that more cells are required to carry oxygen around the body of fish when the solubility of oxygen is low (STOLEN et al., 1984; PASCOLI et al., 2011). Some authors (ADEYEMO et al., 2009; MIREA et al., 2013) observed similar results in Clarius gariepinus. The increased RBC count may be due to stimulation of erythropoietin by elevated demands for $\mathrm{O}_{2}$. The increase in red blood cells was associated with a decrease in Hct and Hgb, as observed by MIREA (2013) in Nile tilapia (Oreochromis niloticus) who were subjected to different water temperatures.

Different fish species show different changes in their hematology after exposure to an increase in water temperature. D. labrax showed higher RBC in a cold water temperature, and this may suggest that, in this species, hematological parameters might have been affected by the photoperiod rather than the temperature (SOLOMON and OKOMODA, 2012). An increase in the total number of circulating erythrocytes causes the parallel increases in Hct and Hgb. The influence of different photoperiods on hematological parameters has been shown in previous research on Clarias Gariepinus reared in a water recirculation system (SOLOMON and OKOMODA, 2012).

Studies relating to the influence of the photoperiod on hematological parameters in fishes are rather few and the responses observed are quite variable (SRIVASTAVA and CHOUDHARY SANJEEV, 2010). 
The temperature of the aquatic environment is important for the survival, distribution and normal metabolism of fish; failure to adapt to temperature fluctuations is generally ascribed to the inability of fish to respond physiologically, with resultant mortality, which is related to changes in their metabolic pathways (ADEYEMO et al., 2003).

Biochemical profile is a good indicator of metabolic adjustment during acclimation to seasonal variations in sea bream (FAGGIO et al., 2014b). Biochemical responses in farmed fish subject to different temperatures are generally measured using reliable parameters, such as glucose, lactate and lipids. An increased water temperature enhanced carbohydrate utilization and liver glycolytic, gluconeogenic and lipogenic capabilities in gilthead sea bream, Sparus aurata (ENES et al., 2006, 2008a; COUTO et al., 2008) and European sea bass, Dicentrarchus labrax (ENES et al., 2008b; MOREIRA et al., 2008). This research is in accordance with our data obtained in Sparus aurata, where we showed an increase in blood glucose in a cold temperature. Some authors (TUNG and SHIAU, 1991) showed that plasma glucose levels in rainbow trout were higher at a water temperature of $8{ }^{\circ} \mathrm{C}$, than at $18{ }^{\circ} \mathrm{C}$. Higher temperatures would promote glucose absorption into cells (HEMRE et al., 2002). In contrast to observations in sea bream, a significant increase in glucose level was noted in our study for D. labrax during warm months, but this result is not supported by the literature data. Physiological responses in teleost fish that are subject to water temperature changes are generally measured using reliable parameters such as glucose, lactate and lipids (VARGAS-CHACOFF et al., 2009; KYPRIANOU et al., 2010). In grass carp and milkfish, exposure to cold causes a rapid increase in glucose levels that afterwards return to the normal range within 2 days (KUO and HSIEH, 2006). In milkfish, changes in fatty acid and glucose metabolism have been shown following exposure to hypothermia (HSIEH et al., 2003; KUO and HSIEH, 2006).

At temperatures below $14{ }^{\circ} \mathrm{C}$, a high blood glucose level is an index of sub-lethal stress and also indicates a retarded metabolism (BEST et al., 2001). Silver catfish Clarias batrachus, stores glucose under cold conditions, resulting in gluconeogenesis, whereas in warm water, it probably consumes glucose. LERMEN et al. (2004) reported that its serum glucose level increased with the fall of temperature. Moreover, the highest blood glucose level was observed in the winter and the lowest during the summer, and correlated to the lowering of the temperature.

The higher level of blood lactate found during the warm months in both species in this study, may be due to the lower level of dissolved oxygen in the water, and the consequent activation of their anaerobic metabolism (OMLIN and WEBER, 2010). When gilthead sea bream is maintained at a critically low temperature, the increase in LDH activity and the accumulation of tissue lactate indicate that hypothermia has stimulated the anaerobic metabolism (KYPRIANOU et al., 2010). These results suggest that production of blood lactate may be greater at warmer temperatures, as the release rate is dependent 
on temperature and the clearance rate is inversely related to it. The lower values showed in colder months is probably due to the oxidation of lactate when oxygen is plenty.

Fish are able to adapt to cold temperatures by changes in their lipid metabolism. Cold treatment in fish, influencing signal transduction, may change the expression of genes associated with lipid metabolism which mainly includes lipid transport, steroid biosynthesis, and glycerol phospholipid biosynthesis (HU et al., 2014). The fluidity of the membranes may be optimized by these changes in the lipid composition at cold temperatures, they may also affect the activity of membrane proteins. Our results showed an increase in lipid composition (cholesterol and triglycerides) in sea bream in colder months. This could be related to the metabolism becoming slower. In many fish species, enhanced lipogenesis is observed at colder temperatures. SHIKATA et al. (1995) reported that fatty acid synthesis from amino acids is elevated with cold acclimation in carp livers. Fats are the fatty acid esters of glycerol and represent the primary energy depots of animals. These are used for long-term energy requirements during periods of inadequate food and energy intake. Another possible explanation for increased serum total cholesterol is endocrine system regulation; cholesterol is the precursor of various steroid hormones (corticosteroid), in particular those involved in physiological adjustments (PANKHURST, 2011).

The increase in plasma protein concentrations is indicative of fluid moving out of the extracellular spaces into the white muscle (WANG et al., 1994), or water moving out of the fish itself, and suggests stress associated with higher temperatures and the consequent higher swimming activity in S. aurata. Our data also showed a significant correlation between the hematological and biochemical parameters of the two species in the two different experimental periods (warm and cold water temperature).

The biometric indices we studied in $S$. aurata and D. labrax during two different seasons showed no statistically significant differences (Table 2). Despite the fact that in both species temperature influences some biochemical parameters (glucose, lactate, triglycerides, cholesterol and total protein) closely related to the metabolism and growth, we did not observe variations in the biometric indexes of species studied during the two different seasons. The temperature variations related to the recorded values do not seem to be a factor negatively associated with reproductive performance.

If $\mathrm{CF}<1.0$ the fish is in poor condition and if $\mathrm{CF}>1.4$ the fish is in good to excellent condition. Our results showed that this factor was always $>1$, so seasonal variations do not compromise the welfare status of either species in our study.

Blood parameters are potentially related to the changes in water temperature, and are highly dependent on seasonal variability. However several other abiotic characteristics of the water environment may also play a part. 


\section{F. Fazio et al.: The effect of temperature and blood parameters in fish}

This study represents an experimental model applied to species farmed in aquaculture and might also be useful for any advance study concerning the acclimation mechanism. The current study will be of help to aquaculture officials responsible for future decisions in the managing and rearing of fish used for human consumption. Further research should be conducted on other species monitored in the natural environment in different seasons, in order to optimize husbandry practices.

\section{Acknowledgements}

The authors would like to thanks Prof. Massimo Mucciardi for statistical analysis of the data.

\section{Conflicts of interest}

The authors declare that they have no conflict of interest.

\section{References}

ADEYEMO, O. K., S. A. AGBEDE, A. O. OlANIYAN., O. A. SHOAGA (2009): The Haematological response of Clarias Gariepinus to changes in acclimation temperature African. J. Biomed. Res. 6, 105-108.

ADEYEMO, O. K., S. A. AGBEDE, A. O OLANIYAN, O. A. SHOAGA (2003): The haematological response of Clarias gariepinus to changes in acclimation temperature. Afr. J. Biomed. Res. 6, 105-108.

AYOOLA, S. O., M. P. KUTON, A. A. IDOWU, A. B. ADELEKUN (2011): Acute toxicity of Nile Tilapia (Orechromis niloticus) juveniles exposed to aqueous and ethanolic extracts of Ipomoea aquatic leaf. Nature \& Science 9, 91-99.

BASU, N., T. NAKANO, E. G. GRAU, G. K. IWAMA (2001): The effects of cortisol on heat shock protein 70 levels in two fish species. Gen. Comp. Endocrinol. 124, 97-105.

BEST, J. H., F. B. EDDY, G. H. CODD (2001): Effects of purified microcystin-LR and cell extracts of Microcystis strains PCC 7813 and CYA 43 on cardiac function in brown trout (Salmo trutta) alevins. Fish. Physiol. Biochem. 24, 171-178.

BOWDEN, T. J., K. D. THOMPSON, A. L. MORGAN, R. M. L. GRATACAP, S. NIKOSKELAINEN (2007): Seasonal variation and the immune response: a fish perspective. Fish Shellfish Immunol. 22, 695-706.

CAZENAVE, J., D. A. WUNDERLIN, A. C. HUED, M. DE LOS ANGELES BISTONI (2005): Haematological parameters in a neotropical fish, Corydoras paleatus (Jenyns, 1842) (Pisces, Callichthyidae), captured from pristine and polluted water. Hydrobiologia 537, 25-33.

CECH, J. J, C. J. BRAUNER (2011): Respiration: an introduction. In: Encyclopedia of Fish Physiology: From Genome to Environment. (Farrel, A. P., Ed.), Elsevier, San Diego, pp. 791795. 
CHATTERJEE, N., A. K. PAL, S. M. MANUSH, T. DAS, S. C. MUKHERJEE (2004): Thermal tolerance and oxygen consumption of Labeo rohita and Cyprinus carpio early fingerings acclimated to three different temperatures. J. Therm. Biol. 29, 265-270.

CHENG, S. Y., C. S. CHEN, J. C. CHEN (2013): Salinity and temperature tolerance of brownmarbled grouper Epinephelus fuscoguttatus. Fish. Physiol. Biochem. 39, 277-286.

COULTER, D. P., T. O. HÖÖK, C. T. MAHAPATRA, S. C. GUFFEY, M. S. SEPULVEDA (2015): Fluctuating water temperatures affect development, physiological responses and cause sex reversal in fathead minnows. Environ. Sci. Technol. 49, 1921-1928.

COUlTER, D. P., M. S. DAVID P. SEPUlVEDA, C. D. TROY, T. O. HÖÖK (2016): Speciesspecific effects of subdaily temperature fluctuations on consumption, growth and stress responses in two physiologically similar fish species. Ecol. Freshw. Fish. 25, 465-475.

COUTO, A., P. ENES, H. PERES, A. OLIVA-TELES (2008): Effect of water temperature and dietary starch on growth and metabolic utilization of diets in gilthead sea bream (Sparus aurata) juveniles. Comp. Biochem. Physiol. A. 151, 45-50.

ELAHEE, K. B., S. BHAGWANT (2007): Hematological and gill histopathological parameters of three tropical fish species from a polluted lagoon on the west coast of Mauritius. Ecotoxicol. Environ. Saf. 68, 361-371.

ENES, P., S. PANSERAT, S. KAUSHIK, A. OLIVA-TELES (2008a): Hepatic glucokinase and glucose-6-phosphatase responses to dietary glucose and starch in gilthead sea bream (Sparus aurata) juveniles reared at two temperatures. Comp. Biochem. Physiol. A. 149, 80-86.

ENES, P., S. PANSERAT, S. KAUSHIK, A. OLIVA-TELES (2008b): Rearing temperature enhances hepatic glucokinase but not glucose-6-phosphatase activities in European sea bass (Dicentrarchus labrax) and gilthead sea bream (Sparus aurata) juveniles fed with the same level of glucose. Comp. Biochem. Physiol. A. 150, 355-358.

ENES, P., S. PANSERAT, S. KAUSHIK, A. OLIVA-TELES (2006): Rapid metabolic adaptation in European sea bass (Dicentrarchus labrax) juveniles fed different carbohydrate sources after heat shock stress. Comp. Biochem. Physiol. A. 145, 73-81.

FAGGIO, C., G. PICCIONE, S. MARAFIOTI, F. ARFUSO, F. TRISCHITTA, G. FORTINO, F. FAZIO (2014a): Monthly variations of haematological parameters of Sparus aurata and Dicentrarchus labrax reared in Mediterranean land off-shore tanks. Cah. Biol. Mar. 45, 437-443.

FAGGIO, C., G. PICCIONE, S. MARAFIOTI, F. ARFUSO, G. FORTINO, F. FAZIO (2014b): Metabolic response to monthly variations of Sparus aurata reared in mediterranean on-shore tanks. Turk. J. Fish. Aquat. Sci. 14, 567-574.

FAZIO, F., F. FILICIOTTO, S. MARAFIOTI, V. DI STEFANO, A. ASSENZA, F. PLACENTI, G. BUSCAINO, G. PICCIONE, S. MAZZOLA (2012): Automatic analysis to assess haematological parameters in farmed gilthead sea bream (Sparus aurata Linneaus, 1758). Mar. Freshw. Behav. Physiol. 45, 63-73.

FAZIO, F., S. MARAFIOTI, F. ARFUSO, G. PICCIONE, C. FAGGIO (2013): Comparative study of the biochemical and haematological parameters of four wild Tyrrhenian fish species. Vet. Med. 58, 576-581. 
F. Fazio et al.: The effect of temperature and blood parameters in fish

GOLLOCK, M J., S. CURRIE, L. H PETERSEN, A. K. GAMPERL (2006): Cardiovascular and haematological responses of Atlantic cod (Gadus morhua) to acute temperature increase. J. Exp. Biol. 209, 2961-2970.

GRACEY, A. Y., E. J. FRASER, W. LI, Y. FANG, R. R. TAYLOR, J. ROGERS, A. BRASS, A. R. COSSINS (2004): Coping with cold: an integrative, multi-tissue analysis of the transcriptome of a poikilothermic vertebrate. Proc. Natl. Acad. Sci. U S A. 101, 16970-16975.

HEMRE, G. I., T. P. MOMMSEN, A. KROGDAHL (2002) Carbohydrate in fish nutrition: effect on growth, glucose metabolism and hepatic enzymes. Aquac. Nutr. 8, 175-194.

HSIEH, S. L., Y. N. CHEN, C. M. KUO (2003): Physiological responses, desaturase activity, and fatty acid composition in milkfish (Chanos chanos) under cold acclimation. Aquaculture. 220, 903-918.

HU, J., F. YOU, Q. WANG, S. WENG, H. LIU, L. WANG, P. J. HANG, X TAN (2014): Transcriptional Responses of Olive Flounder (Paralichthys olivaceus) to Low Temperature. PLoS ONE. 9, e108582.

HUR, J. W., H. R. HABIBI (2007): Physiological response and hematological characteristics of goldfish (Carassius auratus) to water temperature shock. Korean J. Ichthyol. 19, 93-100.

JEONG, J. W., Y. S. KIM, J. C. KANG (2012): Combined effects of temperature and arsenic on hematological parameters of tilapia Oreochromis niloticus. J. Fish. Pathol. 25, 39-46.

KUO, C. M., S. L. HSIEH (2006): Comparisons of physiological and biochemical responses between milkfish (Chanos chanos) and grass carp (Ctenopharyngo donidella) to cold shock. Aquaculture. 251, 525-536.

KYPRIANOU, T. D., H. O. PÖRTNER, A. ANESTIS, B. KOSTOGLOU, K. FEIDANTSIS, B. MICHAELIDIS (2010): Metabolic and molecular stress responses of gilthead seam bream Sparus aurata during exposure to low ambient temperature: an analysis of mechanisms underlying the winter syndrome. Comp. Biochem. Physiol. B. Biochem. Mol. Biol. 180, 10051018.

LERMEN, C. L., R. LAPPE, M. CRESTANI, V. P. VIEIRA, C. R. GIODA, M. R. C. SCHETINGER, B. BALDISSEROTTO, G. MORAES, V. M. MORSCH (2004): Effect of different temperature regimes on metabolic and blood parameters of silver catfish Rhamdia quelen. Aquaculture 239, 497-507.

LOHNER, T. W., R. J. REASH, V. E. WILLET, L. A. ROSE (2001): Assessment of tolerant sunfish populations (Lepomi ssp.) inhabiting selenium-laden coal ash effluents. 1. Hematological and population level assessment. Ecotoxicol. Environ. Saf. 50, 203-216.

MAURI, I., A. ROMEO, L. ACERETE, S. MACKENZIE, N. ROHER, A. CALLOL, I. CANO, M. C. ALVAREZ, L. TORT (2011): Changes in complement responses in Gilthead sea bream (Sparus aurata) and European sea bass (Dicentrarchus labrax) under crowding stress, plus viral and bacterial challenges. Fish Shellfish Immunol. 30, 182-188.

MIREA, C., V. CRISTEA, R. I. GRECU, L. DEDIU, V. ION (2013): Hematological and biochemical characterization of Nile tilápia (Oreochromis niloticus, Linnaeus, 1758) reared intensively in 
a recirculating aquaculture system in relation to water temperature. Anim. Sci. Biotech. 46, 234-237.

MOREIRA, I. S., H. PERES, A. COUTO, P. ENES, A. OLIVA-TELES (2008): Temperature and dietary carbohydrate level effects on performance and metabolic utilisation of diets in European sea bass (Dicentrarchus labrax) juveniles. Aquaculture. 27, 153-160.

OMLIN, T., J. M. WEBER (2010): Hypoxia stimulates lactate disposal in rainbow trout. J. Exp. Biol. 213, 3802-3809.

O'NEAL, C. C., C. R. WEIRICH (2001): Effects of low level salinity on Production and haematological parameters of channel catfish (Ictalurus punctatus) reared in multi-crop ponds. In: Book of abstract. Aquaculture 2001. International Triennial Conference of World Aquaculture Society. Jan. 21-25, 2001. Disney Coronado Springs Resort Lake Buena Vista, Florida, p. 484.

PANKHURST, N. W. (2011): The endocrinology of stress in fish: An environmental perspective. Gen. Comp. Endocrinol. 170, 265-275.

PARISI, G., G. TEROVA, L. GASCO, G. PICCOLO, A. RONCARATI, V. M. MORETTI, G. CENTODUCATI, P. P. GATTA, A. PAIS (2014): Current status and future perspectives of Italian finis aquaculture. Rev. Fish Biol. Fisher. 24, 15-73.

PASCOLI, F., G. S. LANZANO, E. NEGRATO, C. POLTRONIERI, A. TROCINO, G. RADAELLI, D. BERTOTTO (2011): Seasonal effects on hematological and innate immune parameters in sea bass Dicentrarchus labrax. Fish Shellfish Immunol. 31, 1081-1087.

PERCIN, F., S. KONYALIOGLU (2008): Serum biochemical profiles of captive and wild northern bluefin tuna, (Thunnus thynnus L. 1758) in the Eastern Mediterranean. Aquacult. Res. 39, 945-953.

PERCIN, F., S. KONYALIOGLU, K. FIRAT, S. SAKA (2010): Serum electrolytes of wild and captive bluefin tuna (Thunnus thynnus L.) in Turkish Seas. J. Anim. Vet. Adv. 16, 207-2213.

RANZANI-PAIVA M. J. T., E. ROMAGOSA, C ISHIKAWA (2005): Hematological parameters of "cachara" Pseudoplatystoma fasciatum Linnaeus, 1766 (Osteichthyes, Pimelodidae), reared in captivity. Bol. Inst. Pesca. 31, 47-53.

SCOTT, G. R., I. A. JOHNSTON (2012): Temperature during embryonic development has persistent effects on thermal acclimation capacity in zebrafish. Proc. Natl. Acad. Sci. U S A. $109,14247-14252$.

SHIKATA T., S. IWANAGA, S. SHIMENO (1995): Regulation of carbohydrate metabolism in fish. Metabolic response to acclimation temperature in carp. Fisheries Sci. 61, 512-516.

SOLOMON S. G., V. T. OKOMODA (2012): Effects of photoperiod on the haematological parameters of clarias gariepinus fingerlings reared in water recirculatory system. J. Stress Physiol. Biochem. 8, 247-256.

SRIVASTAVA, S., K. CHOUDHARY SANJEEV: Effect of artificial photoperiod on the blood cell indices of the catfish, Clarias batrachus. J. Stress Phisiol. Biochem. 6, 22-32. 
STOLEN, J. S., S. DRAXLER, J. J. NAGLE (1984): A comparison of temperature mediated immunomodulation between two species of flounder. Immunol. Comm. 13, 245-253.

TUNG, P. H., S. Y. SHIAU (1991) Effects of meal frequency on growth performance of hybrid tilapia, Oreochromis niloticus $\times$ O. aureus, fed different carbohydrate diets. Aquaculture 92 , 343-350.

VARGAS-CHACOFF, L., F. J. ARJONA, S. POLAKOF, M. P. DEL RÍO, J. L. SOENGAS, J. M. MANCERA (2009): Interactive effects of environmental salinity and temperature on metabolic responses of gilthead sea bream Sparus aurata. Comp. Biochem. Physiol. A. Mol. Integr. Physiol. 154, 417-424.

YANG, J. H., I. K. YEO (2004): Physiological studies on acute water-temperature stress of olive flounder (Paralichthys olivaceus). Korean J. Ichthyol. 16, 19-26.

WANG, Y., G. J. F. HEIGENHAUSER, C. M. WOOD (1994): Integrated responses to exhaustive exercise and recovery in rainbow trout white muscle: acid-base, phosphogen, carbohydrate, lipid, ammonia, fluid volume and electrolyte metabolism. J. Exp. Biol. 195, 227-258.

FAZio, F., V. FERRANTelli, G. PICCIONe, C. SAOCA, M. LEVANTI, M. MUCCIARDI: Biokemijski i hematološki pokazatelji lubina (Dicentrarchus labrax Linnaeus, 1758.) i komarče (Sparus aurata Linnaeus, 1758.) u odnosu na temperaturu. Vet. arhiv 88, 397-411, 2018.

\section{SAŽETAK}

Cilj istraživanja bio je procijeniti utjecaj temperature vode na biokemijske i hematološke pokazatelje kod dvije različite vrste farmski uzgajanih riba: lubina (Dicentrarchus labrax Linnaeus, 1758.) i komarče (Sparus aurata Linnaeus, 1758.). Ukupno 60 uzoraka krvi prikupljeno je od svake vrste, uzgajane na Siciliji, tijekom hladne (veljača, srednja temperatura $13,40{ }^{\circ} \mathrm{C}$ ) i tople (listopad, srednja temperatura $23,20{ }^{\circ} \mathrm{C}$ ) sezone. Analizirani su biokemijski pokazatelji (glukoza, laktat, kolesterol, trigliceridi i ukupne bjelančevine) i hematološki pokazatelji (broj eritrocita, koncentracija hemoglobina, hematokrit, prosječni volumen eritrocita $\mathrm{MCV}$, prosječni hemoglobin u eritrocitu $\mathrm{MCH}$ i prosječna koncentracija hemoglobina u eritrocitu MCHC). Značajne razlike $(\mathrm{P}<0,05)$ zabilježene su za glukozu, laktat, trigliceride, kolesterol i ukupne bjelančevine te za broj eritrocita, koncentraciju hemoglobina, hematokrit, MCV i MCH. Informacije utvrđene ovim istraživanjem mogle bi biti korisne za optimalnu uzgojnu praksu u akvakulturi kao i za praćenje promjena u zdravstvenom statusu riba.

Ključne riječi: krvni pokazatelji; farmski uzgoj riba; rast; sezona; temperatura vode 
